\title{
Grazing impacts on litter and roots: perennial versus annu- al grasses
}

\author{
E. MAPFUMO, M. A. NAETH, V. S. BARON, A.C. DICK AND D. S. CHANASYK
}

Authors are Post-doctoral Fellow and Professor in Department of Renewable Resources, University of Alberta, Edmonton, Alberta, Canada T6G 2H1, Research Scientist and research scientist with Lacombe Research Centre, Agriculture and Agri-Food Canada, 6000 C\&E Trail, Lacombe, Alberta, Canada T4L 1W1, and Professor in Department of Renewable Resources, University of Alberta, Edmonton, Alberta, Canada T6G 2 HI.

\section{Abstract}

Soil carbon (C) and nitrogen (N) storage in grasslands is a function of litter and root mass production. Research on how annual grasses compare with perennials for above ground and below ground mass production, and contributions to the soil $\mathrm{C}$ pool under pasture management is scarce. The objective of this research was to evaluate grazing intensity effects on litter and root mass, $\mathrm{C}$ and $\mathrm{N}$ pools of perennial grasses, smooth bromegrass (Bromus inermis L.) and meadow bromegrass (Bromus riparius Rhem.), and the annual grass, winter triticale (X Triticosecale Wittmack). Litter mass and $\mathrm{C}$ pool for the perennial grasses were greater than those for triticale. Litter $\mathrm{C}$ and $\mathrm{N}$ pools generally decreased with increased grazing intensity. Root mass was greater for the perennial grasses than for triticale at all grazing intensities. Meadow bromegrass generally produced more root mass than smooth bromegrass. Root $\mathrm{C}$ and $\mathrm{N}$ pools for triticale were 31 and $27 \%$, respectively, of that for the perennial grasses. Estimated total $\mathbf{C}$ contribution (roots and litter) to the resistant soil organic $\mathbf{C}$ pool was 1.5 times greater for light compared to heavy grazing. Total C (litter + root) contribution for perennial grasses was 2.7 times greater than that for triticale. Perennial grasses provided a larger litter base and root system that promote greater storage of $\mathrm{C}$ in the soil compared with triticale.

Key Words: annuals, organic C, perennials, total N, sequestration

Grazing has a major impact on litter, roots, and soil characteristics. Litter herein refers to all dead (standing and fallen) plant material above the soil surface (Naeth 1988). Litter reduces soil erosion by reducing runoff and improves soil structure and fertility through addition of organic matter (Naeth 1988). Bare soils are more susceptible to raindrop impact and aggregate break down which can lead to surface sealing and increased erosion. Litter is especially critical at snowmelt and during intense rainfall events that can potentially remove large amounts of surface soil and nutrients (Chanasyk and Woytowich 1987). The amount of litter in a pasture is a function of forage growth, senescence, harvest and decomposition (Coleman 1992). Grazing affects plant characteristics primarily via biomass and litter removal. Standing and fallen litter mass and vegetation ground cover generally decrease while amount of bare ground increases with increased grazing

Funding from the Canada-Alberta Environmentally Sustainable Agriculture Agreement (CAESA) is gratefully acknowledged. Thanks are extended to David Young, Kelly Ostermann, Pola Genoway, Kirsten Gregorwich and Mae Elsinger for field assistance.

Manuscript accepted 17 Mar. 2001

\section{Resumen}

El almacenamiento de nitrógeno $(\mathrm{N})$ y carbón $($ e en los suelos de pastizal esta en función de la producción de mantillo y biomasa radical. Hay una escases de investigación respecto a como los zacates anuales, comparados con los perennes, producen biomasa aérea y subterránea y las contribuciones a la reserva de $\mathbf{C}$ del suelo bajo praderas menejadas. El objetivo de esta investigación fue evaluar el efecto de la intensidad de apacentamiento en el mantillo y la biomasa de raíces de los zacates perennes, "Smooth bromegrass" (Bromus inermis L.) y "Meadow bromegrass" (Bromus riparius Rhem.) y de la especie anual de triticales invernal. (X Triticosecale Wittmack) y en las reservas de $\mathrm{C}$ y $\mathrm{N}$. La biomasa de mantillo y la reserva de $\mathrm{C}$ de los zacates perennes fue mayor que la del triticale. Las reservas de $\mathbf{C}$ y $\mathbf{N}$ del mantillo generalmente diminuyeron al aumentar la intensidad de apacentamiento. La biomasa de raices fue mayor para los zacates perennes que para el triticale, esto se registró en todas las intensidades de apacentamiento. El "Meadow bromegrass" generalmente produjo más biomasa de raíces que el "Smooth bromegrass". Las reservas de $\mathbf{C}$ y $\mathbf{N}$ de las raíces del triticale fueron 31 y $27 \%$, respectivamente, de las reservas registradas en los zacates perennes.. La contribución total estimada de $\mathbf{C}$ (raices y mantillo) a la reserva de $\mathbf{C}$ del suelo orgánico resistente fue 1.5 veces mayor para el apacentamiento ligero que para el apacentamiento fuerte. La contribución total de $\mathbf{C}$ (mantillo + raices) de los zacates perennes fue 2.7 veces mayor que la del triticale. Los zacates perennes proveyeron una mayor base de mantillo y sistema radical lo que promueve un mayor alamcenamiento de $\mathbf{C}$ en el suelo comaprado con el triticale.

intensity (Naeth et al. 1991).

Grasslands have the ability to store substantial pools of soil $\mathrm{C}$ and N. Grasslands contain about $10 \%$ of the world C pool (Parton et al. 1995). In temperate regions grasslands may release as much as $40 \%$ of their $\mathrm{C}$ through respiration when they are cultivated and converted to grains and oilseeds (Burke et al. 1995). This narrows the soil carbon-to-nitrogen ratio $(\mathrm{C}: \mathrm{N})$ favoring the release of soil $\mathrm{N}$ through $\mathrm{N}$ mineralization processes (Wedin 1996). Perennial pastures and hay crops on the Canadian prairies are usually found as a 2 to 9 year sequence in a forage-cereal rotation (Entz et al. 1995). During this time they contribute to soil $\mathrm{C}$ and $\mathrm{N}$ pools and after being broken enhance yields of cereal crops (Campbell et al. 1990, Entz et al. 1995). The residue that remains goes into the litter pool and subsequently a portion is sequestered in soil. Initial break down results in large losses of organic $\mathrm{C}$ stored under grasslands and annual cultivation exacerbates the loss (Campbell et al. 1990). 
The objective of this study was to quantify grazing management effects on litter and root mass, litter and $\operatorname{root} \mathrm{C}$ and $\mathrm{N}$ pools in 2 perennial pastures, smooth bromegrass (Bromus inermis L.) and meadow bromegrass (Bromus riparius L.), and triticale (X Triticosecale Wittmack) when grazed at light to heavy grazing intensities.

\section{Materials and Methods}

\section{Site Description and Meteorolo- gical Conditions}

The study was conducted at Lacombe, Alberta $\left(52^{\circ} 28^{\prime} \mathrm{N} ; 113^{\circ} 45^{\prime} \mathrm{W} ; 847 \mathrm{~m}\right)$, on a Typic Haplustoll derived from glaciolacustrine parent material. The upper 15 $\mathrm{cm}$ of soil averaged $15 \%$ clay, $34 \%$ silt, and $51 \%$ sand. Soil $\mathrm{pH}$ using distilled water was 5.4 and the sodium adsorption ratio was 0.2 .

Total precipitation between April and October for 1993, 1994, 1995, and 1996 was $416,530,408$, and $383 \mathrm{~mm}$, respectively. The long-term normal annual precipitation (89-year average) was $362 \mathrm{~mm}$. Mean air temperature between April and October ranged from 6.5 to $13.6^{\circ} \mathrm{C}$ in $1993,7.7$ to $17.1^{\circ} \mathrm{C}$ in $1994,5.8$ to $15.9^{\circ}$ $\mathrm{C}$ in 1995 and 2.8 to $16.1^{\circ} \mathrm{C}$ in 1996. During the winter months (November to March) the total precipitation was $89 \mathrm{~mm}$ in $1993 / 1994,30 \mathrm{~mm}$ in $1994 / 1995,88$ $\mathrm{mm}$ in $1995 / 1996$, and $235 \mathrm{~mm}$ in 1996/97.

\section{Experimental Design, Species and Grazing Treatments}

Before being broken the site had been under extensive grazing management of 15 -year old perennial grass pasture that was composed of smooth bromegrass (Bromus inermis L.), quackgrass (Elytrigia repens L.) and Kentucky bluegrass (Poa pratensis L.). Cultivation of the plot area commenced in summer 1992 so that new species could be established in 1993. Data collection was initiated in 1994.

The experimental field plots were a randomized complete block design with 3 grazing treatments, 3 forage species and 4 replications as blocks. Each plot was $33 \times$ $9 \mathrm{~m}$ and was subjected to 1 of 3 grazing treatments (heavy, medium, light). The upper two experimental blocks were eastfacing on a 4 to $6 \%$ slope, while the other 2 blocks were on flat land.

Three forage species, 2 perennials and an annual, with potentially differing abili- ties to produce litter were used. Carlton smooth bromegrass (Bromus inermis L.) and Paddock meadow bromegrass (Bromus riparius $\mathrm{Rhem}$.) were the perennial species; Pika winter triticale ( $X$ Triticosecale Wittmack) was the annual species. Smooth bromegrass is a rhizomatous species whereas meadow bromegrass is a bunchgrass such that differences in root and litter masses could be expected. Prior to seeding the experimental area received a broadcast application of 8,31 , 31 , and $5 \mathrm{~kg} \mathrm{ha}^{-1}$ of $\mathrm{N}, \mathrm{P}_{2} \mathrm{O}_{5}, \mathrm{~K}_{2} \mathrm{O}$, and $\mathrm{S}$, respectively. This was followed by a light cultivation and packing. Smooth bromegrass was seeded at $11.2 \mathrm{~kg} \mathrm{ha}^{-1}$ and meadow bromegrass at $16.8 \mathrm{~kg} \mathrm{ha}^{-1}$. Spredor II alfalfa (Medicago sativa L.) was seeded with each grass at $1 \mathrm{~kg} \mathrm{ha}^{-1}$. Alfalfa had almost totally disappeared by the time measurements were taken in 1996. Perennial species were broadcast seeded with a Model HHBS-125 HandiSpred Lawn and Garden Seeder-Spreader. Seeding was followed by one pass with a diamond tooth harrow and one pass with a crowfoot packer. Each spring 100, 50, and $50 \mathrm{~kg} \mathrm{ha}^{-1}$ of $\mathrm{N}, \mathrm{P}_{2} \mathrm{O}_{5}$ and $\mathrm{K}_{2} \mathrm{O}$, respectively were broadcast over the experimental area. Such amounts of fertilizer are not uncommon in intensively grazed pastures. Annual plots were rototilled to a depth of $10 \mathrm{~cm}$ and seeded to triticale at $135 \mathrm{~kg} \mathrm{ha}^{-1}$ in 2 passes with row spacing of $12.5 \mathrm{~cm}$. A herbicide, 2-methyl-4-chlorophenoxyacetic acid (MCPA), was applied in spring each year at a rate of $600 \mathrm{~g}_{\text {ai }} \mathrm{ha}^{-1}$ in 1994 to 1996 and at a rate of $900 \mathrm{~g}$ ai ha ${ }^{-1}$ in 1997 , to the triticale to control weeds. No herbicides were applied in perennial grass plots. Residue (all above ground plant material remaining after the last grazing of the previous season) was left in place until spring (end of April) seeding.

All plots were grazed with one-year old crossbred beef heifers. In 1993, unquantified light grazing was used to reduce forage biomass by approximately $50 \%$ on all plots. Beginning in 1994, up to 8 animals were placed on a treatment at one time, depending on the intensity of grazing desired. Water was constantly available to cattle so as not to disrupt grazing habits. Grazing events lasted usually less than 24 hours.

Forage height was used to define grazing intensity. Grazing started when forages reached a target maximum and ceased when a target minimum height was reached. Target heights varied among species and were set according to the species morphology, the desired amount of litter and the amount of bare ground deemed appropriate for that treatment.
Forage heights were determined using a diskmeter (Bransby et al. 1977) and the average of 10 disk heights was calculated. The diskmeter was used in this case to maintain consistency in assessing forage availability. For perennials, heavy, medium and light grazing was initiated at 13 , 17 , and $26 \mathrm{~cm}$ and stopped at 6,5 , and 7 $\mathrm{cm}$, respectively when averaged over all grazing events within a year. Comparable figures for triticale were 11,12 , and $21 \mathrm{~cm}$ on entry and 3,4 , and $6 \mathrm{~cm}$ on exit of animals from heavy, medium and light intensity grazing. Perennials were grazed 7,5 , and 3 times and the annuals 4, 4, and 2 times for heavy, medium, and light grazings, respectively within the 3 study years. Averaged over 3 years the animal unit months per hectare (AUM ha' ${ }^{-1}$, based on approximately $450 \mathrm{~kg}$ animal) for perennials was 45.2, 24.4, and 19.6 $\mathrm{AUM} \mathrm{ha}^{-1}$, for heavy, medium and light grazing, respectively. For triticale this was 23.3, 13.5, and 9.8 AUM ha $^{-1}$, for heavy, medium, and light grazing, respectively.

\section{Vegetation Sampling}

Litter samples were collected in fall 1994, 1995, and 1996 and in spring 1995, 1996, and 1997. Spring sampling occurred in late April, prior to cultivation of annual plots when perennials had already begun growing. Fall samples were collected between end of September and early October, after the final grazing event each year. Samples were collected from 3 randomly selected sites within each plot in each replicate. All vegetation within a $0.05-\mathrm{m}^{2}$ quadrat was clipped at ground level and the surface soil was raked with a hand-fork to remove litter above the soilmineral surface. All material collected was separated into live (any green material) and dead components before oven-drying at $60^{\circ} \mathrm{C}$ to determine litter mass (all dead material standing and fallen).

\section{Carbon and Nitrogen Pools in Litter}

Three litter samples taken from each plot were combined before determination of the carbon $(\mathrm{C})$ and nitrogen $(\mathrm{N})$ fractions in litter using the Leco Carbon Determinator (Model CN 2000, Leco Corp., St. Joseph, Minn.) and the Kjeldahl digestion method (McGill and Figueiredo 1993), respectively. The litter $\mathrm{C}$ and $\mathrm{N}$ pools were the product of litter mass $(\mathrm{kg}$ $\mathrm{ha}^{-1}$ ) multiplied by percent $\mathrm{C}$ or $\mathrm{N}$ content. Litter $\mathrm{C}$ and $\mathrm{N}$ pools were compared among grazing levels, plant species, and years. 


\section{Root Sampling}

Soil cores were taken in October 1996 and 1997 to a depth of $60 \mathrm{~cm}$ from 3 random locations in non-crown areas in each plot in each replicate using a hydraulically powered sampler with a $5.1-\mathrm{cm}$ diameter probe. Soil cores were separated into depth segments of 0 to 5,5 to 15,15 to 30 , and 30 to $60 \mathrm{~cm}$ and bulked by depth for each plot. Samples were transported from the field immediately, spread in shallow pans and dried at room temperature in a forced-air dryer. Roots were separated from soil with a hydropneumatic elutriation system (Smucker et al. 1982). No attempt was made to differentiate between live and dead roots. Root material was collected on a fine-mesh screen and transferred by washing on to Whatman No. 4 filter papers $9 \mathrm{~cm}$ in diameter. The papers and roots were dried in a forced air oven at $85^{\circ} \mathrm{C}$ for at least 24 hours and then weighed. Root mass per hectare for each sampling depth was calculated from the sample core size. Due to small sample sizes, the samples for each depth within each replicate were combined and ground through a cyclone mill (UDY Corporation, Boulder, Colo.) to pass a $0.5-\mathrm{mm}$ screen. Total $\mathrm{C}$ and total $\mathrm{N}$ were measured with a Leco Carbon Determinator (Model CN 2000, Leco Corp., St. Joseph, Minn.) and the Kjeldahl digestion method (McGill and Figueiredo 1993), respectively. Root masses for the 0 to $15 \mathrm{~cm}$ and 0 to $60 \mathrm{~cm}$ were examined to determine if there were differences among grazing levels and species in the total root mass (0 to $60 \mathrm{~cm}$ ) and in the amount of roots found in the plough layer $(0$ to $15 \mathrm{~cm})$.

\section{Statistical Analyses}

Statistical analyses was conducted using the SAS statistical package generalized linear models procedure (SAS Institute 1989). Analyses of litter mass, litter C pool, litter $\mathrm{N}$ pool, root mass, root $\mathrm{C}$ pool, and root $\mathrm{N}$ pool were conducted using a split-split-plot design repeated across years. Grazing intensity and species were main plot effects tested for significance using replicate within (grazing $\mathrm{X}$ species) as the error term, years were a subplot effect tested with replicate within years as the error term, and the interactions were sub-subplot effects tested with the residual error (Steel and Torrie 1980). Where the F-test indicated a significant $(P \leq 0.05)$ effect, means were separated by calculation of least significance difference (LSD) using the appropriate error mean squares (Gomez and Gomez 1984)

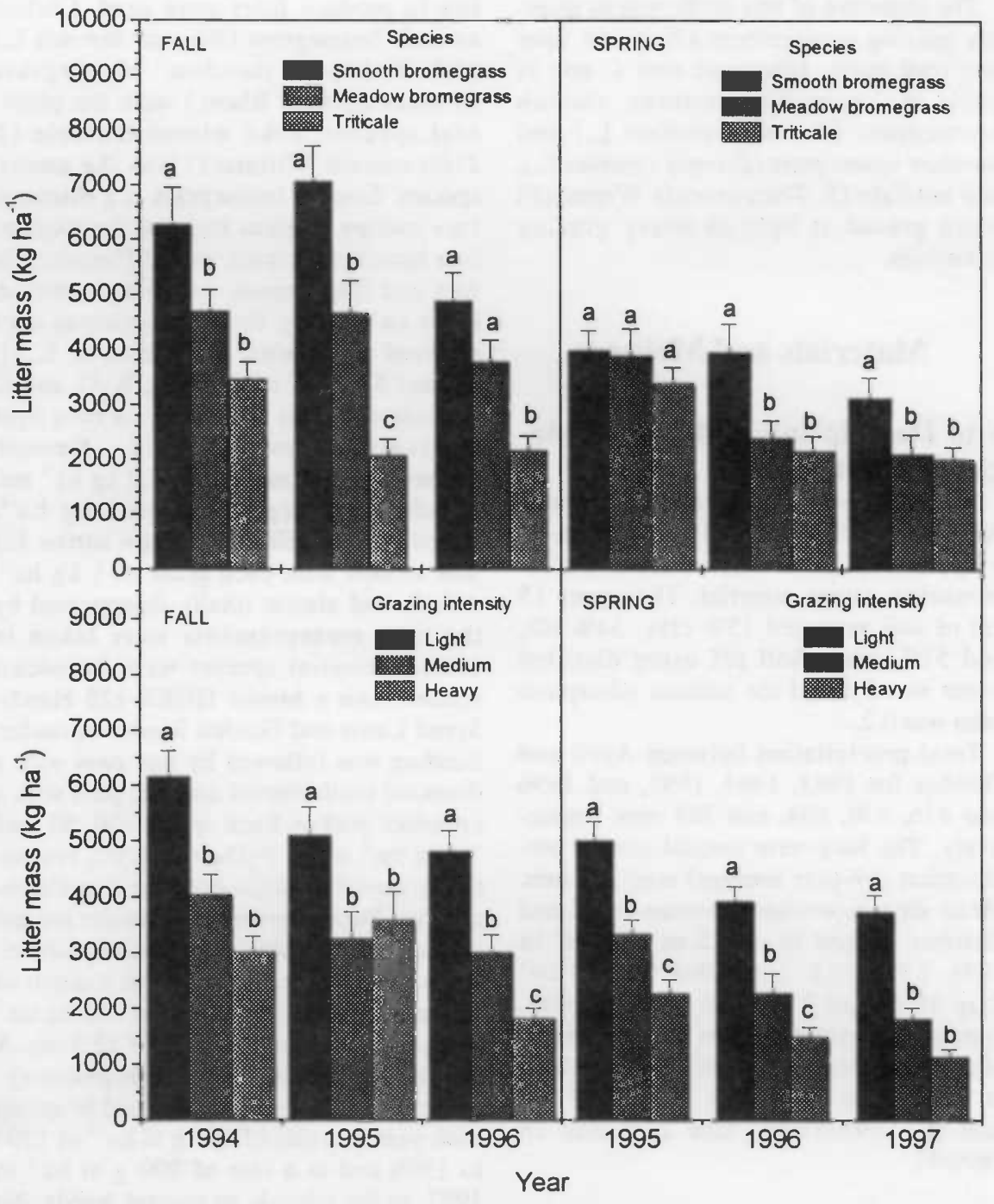

Fig. 1. Litter mass $\left(\mathrm{kg} \mathrm{ha}^{-1}\right)$ in fall and spring under different species, years, and grazing intensities.

\section{Results}

\section{Litter Mass, Carbon, and Nitrogen Pools}

Litter mass in fall was greater for perennial grasses than for triticale whereas in spring litter mass for smooth bromegrass was greater than that for other species (Fig. 1). Averaged across years, litter mass in fall for triticale was only $48 \%$ that for perennials whereas in spring it was $78 \%$. In both spring and fall, litter mass decreased with increasing grazing intensity (Fig. 1). Heavy and medium grazing had average fall litter masses 53 and $64 \%$ that for light 'grazing, respectively. However, in spring, litter masses for heavy and medium grazing were 39 and $59 \%$ that for light grazing, respectively.

Differences in litter $\mathrm{C}$ pool among species were evident in fall of all years. In all years the $\mathrm{C}$ pool in fall was greatest for smooth bromegrass and smallest for triticale whereas in spring litter $C$ pool differences among species were low and inconsistent (Fig. 2). In spring, litter C for triticale across grazing intensities was $72 \%$ of that for perennials, and litter masses for heavy and medium grazing were, respectively, 36 and $57 \%$ of that for light grazing. In general, the litter $\mathrm{C}$ pool in both fall and spring decreased with increased grazing intensity (Fig. 2). In 4 out of 6 cases the $\mathrm{C}$ pool of the heavy grazing treatment was less than $50 \%$ of that for the light grazing treatment.

The litter $\mathrm{N}$ pool in 2 out of 3 years was greater for perennials than for triticale, with smooth bromegrass having the largest $\mathrm{N}$ pool of all forages and triticale having the smallest (Fig. 3). Litter $\mathrm{N}$ pool in spring for triticale was $71 \%$ of that for 
perennials. In fall, the heavy grazed treatment had a smaller $\mathrm{N}$ pool in litter than the light grazed treatment whereas the $\mathrm{N}$ pool of the medium grazed treatment was intermediate. Furthermore, heavy and medium grazing litter masses were 41 and $62 \%$ of that for light grazing, respectively.

Litter $\mathrm{C}: \mathrm{N}$ ratios ranged between 13:1 and 16:1 and were similar among forages in both fall and spring (Fig. 4). The litter $\mathrm{C}: \mathrm{N}$ ratio in fall generally decreased with ter $\mathrm{C}: \mathrm{N}$ ratios for heavily grazed forages were lower than that for lightly grazed forages in 2 out of 3 years (Fig. 4).

\section{Root Mass, Carbon and Nitrogen Pools}

Trends among grazing intensities for accumulated root mass to $15 \mathrm{~cm}$ or $60 \mathrm{~cm}$ (Table 1) were similar. The majority of root material (52 to $60 \%$ ) existed in the upper $15 \mathrm{~cm}$. Root mass of triticale was always substantially less than that of the perennial grasses throughout the soil profile (Table 1). Root mass of the perennial grasses was 2.6 to 5.2 times that of triticale within grazing levels.

Grazing intensity affected root mass of the species differently (Table 1). Over the $60-\mathrm{cm}$ depth and within the 0 to $15-\mathrm{cm}$ depth root mass of triticale was unaffected by grazing intensity. Root mass of smooth bromegrass maximized at the medium grazing intensity for the 0 to $60-\mathrm{cm}$ depth interval and decreased between medium and light grazing intensities for the 0 to 15-cm depth interval (Table 1). By contrast root mass of meadow bromegrass increased from medium to light grazing intensity for the 0 to $60-\mathrm{cm}$ depth interval and for the 0 to $15-\mathrm{cm}$ depth interval (Table 1).

Perennial grasses always had signifiincreased grazing intensity. For spring, lit-

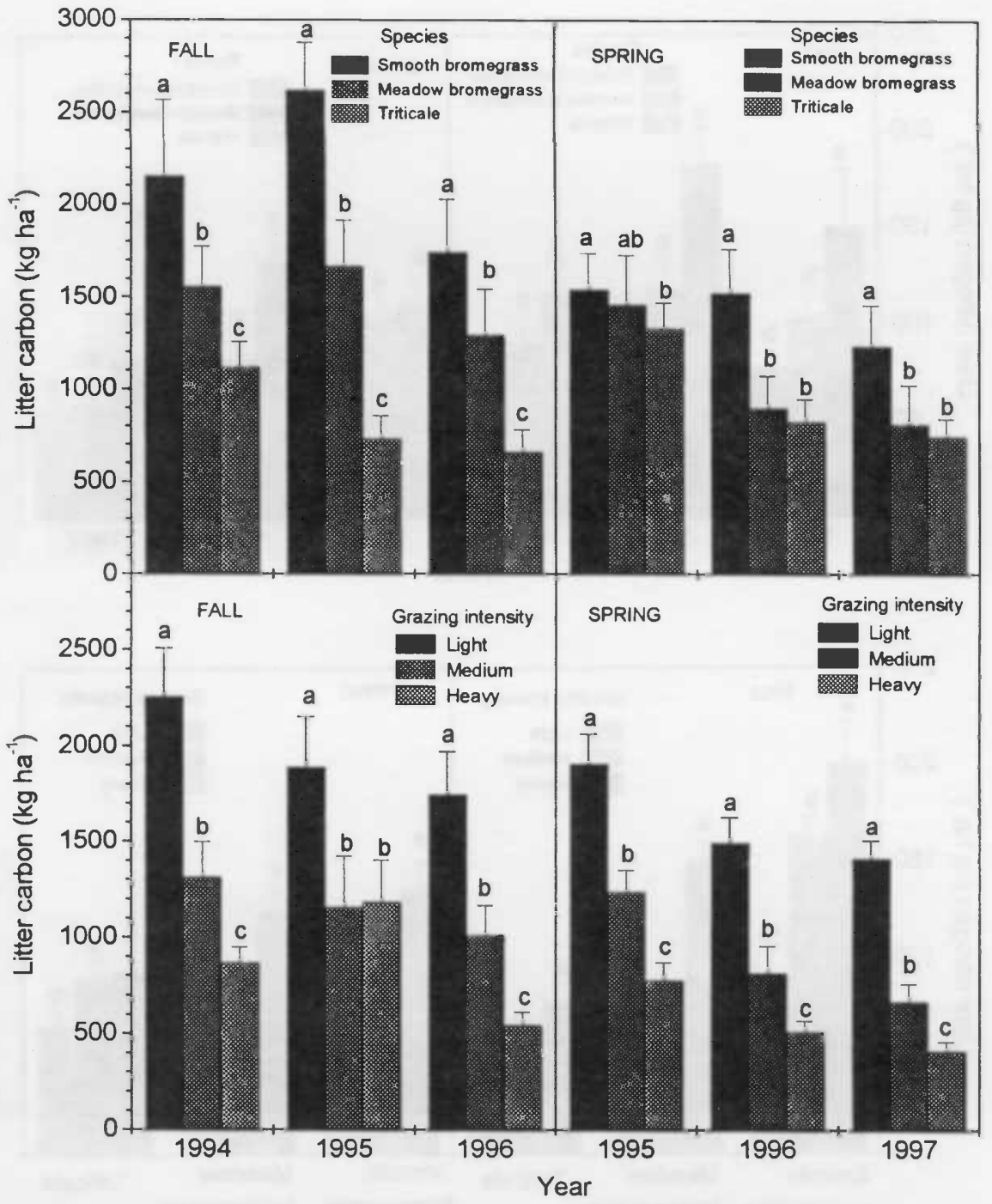

Fig. 2. Litter carbon $\left(\mathrm{kg} \mathrm{ha}^{-1}\right)$ in fall and spring under different species, years and grazing intensities.

cantly higher root $\mathrm{C}$ and $\mathrm{N}$ pools than triticale (Table 2). Averaged over grazing level triticale had 25 to $30 \%$ of the root C

Table 1. Root mass $\left(\mathrm{kg} \mathrm{ha}^{-1}\right)$ in the surface $(0$ to $15 \mathrm{~cm})$ segment and for the whole profile $(0$ to 60 $\mathrm{cm})$ under 3 grass species subjected to three grazing intensities averaged over 2 years.

\begin{tabular}{lccc}
\hline \hline & \multicolumn{3}{c}{ Grazing intensity } \\
\cline { 2 - 4 } Species & Light & Medium & Heavy \\
\hline & & \multicolumn{3}{c}{ Surface $(0-15 \mathrm{~cm})$} \\
Smooth bromegrass & $1390 \pm 164 \mathrm{bB}$ & $2020 \pm 280 \mathrm{aA}$ & $1720 \pm 275 \mathrm{aA}$ \\
Meadow bromegrass & $2610 \pm 402 \mathrm{aA}$ & $2090 \pm 222 \mathrm{aB}$ & $1540 \pm 382 \mathrm{aC}$ \\
Triticale & $530 \pm 68 \mathrm{cA}$ & $800 \pm 209 \mathrm{bA}$ & $480 \pm 125 \mathrm{bA}$ \\
& & $\underline{T}$ & \\
Smotal $(0-60 \mathrm{~cm})$ & \\
Meadow bromegrass & $2840 \pm 263 \mathrm{bB}$ & $3520 \pm 243 \mathrm{aA}$ & $3120 \pm 295 \mathrm{aB}$ \\
Triticale & $4890 \pm 539 \mathrm{aA}$ & $3730 \pm 331 \mathrm{aB}$ & $3320 \pm 728 \mathrm{aB}$ \\
& $940 \pm 82 \mathrm{cA}$ & $1320 \pm 246 \mathrm{bA}$ & $810 \pm 133 \mathrm{bA}$ \\
\hline
\end{tabular}

Values presented are means \pm standard errors for 8 replicates.

Means within column and depth increment followed by different lower case letters indicate significant difference among species within grazing intensities (Least Squares Means, $\mathrm{P} \leq 0.05$ ).

Means within row and depth increment followed by upper case letters indicate significant difference among grazing intensities within species (Least Squares Means, $P \leq 0.05$ ). and 28 to $32 \%$ of the root $\mathrm{N}$ pool size of perennial grasses. For smooth bromegrass the $\mathrm{C}$ and $\mathrm{N}$ pools to $60 \mathrm{~cm}$ depth were greatest in the medium grazing intensity. The root $\mathrm{C}$ pool for meadow bromegrass under heavy grazing intensity was $67 \%$ of that under light grazing intensity. The root $\mathrm{N}$ pool for meadow bromegrass increased up to the light grazing intensity with the heavy grazing intensity $75 \%$ of the light. The widest range among species for $\mathrm{C}$ and $\mathrm{N}$ pool size occurred at the light grazing intensity. At this grazing intensity, triticale and smooth bromegrass were 20 and $81 \%$, respectively, of meadow bromegrass for the root $\mathrm{C}$ pool, and 28 and $85 \%$, respectively, of meadow bromegrass for the root $\mathrm{N}$ pool.

Significant variation was observed among species and from year to year for root $\mathrm{C}: \mathrm{N}$ ratio (data not shown). There 

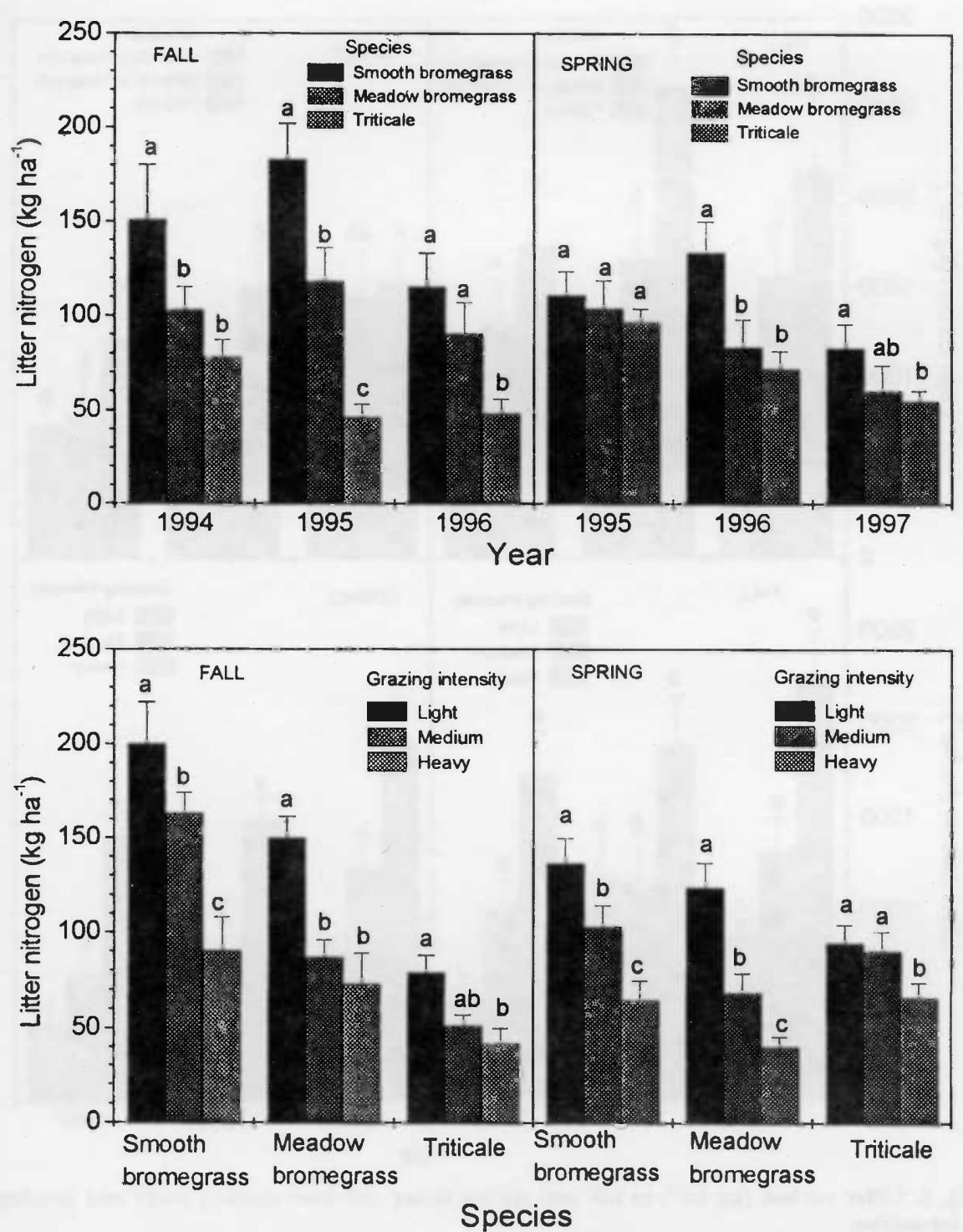

Fig. 3. Litter nitrogen $\left(\mathrm{kg} \mathrm{h}^{\mathrm{a}-\mathrm{l}}\right)$ in fall and spring under different species, years and grazing intensities.

was a trend for triticale to have a lower

$\mathrm{C}: \mathrm{N}$ ratio than smooth and meadow

bromegrass, but the difference was only significant in 1997. The year-to-year dif-

Table 2. Carbon and nitrogen pools in roots of annual and perennial grasses subjected to light, medium and heavy grazing.

\begin{tabular}{lccc}
\hline \hline & \multicolumn{4}{c}{ Grazing intensity } \\
\cline { 2 - 4 } Species & Light & Medium & Heavy \\
\hline \multirow{2}{*}{ Smooth bromegrass } & $1190 \pm 117 \mathrm{bB}$ & $1490 \pm 117 \mathrm{aA}$ & $1270 \pm 123 \mathrm{aB}$ \\
Meadow bromegrass & $1960 \pm 214 \mathrm{aA}$ & $1450 \pm 107 \mathrm{aB}$ & $1320 \pm 271 \mathrm{aB}$ \\
Triticale & $400 \pm 34 \mathrm{cA}$ & $460 \pm 86 \mathrm{bA}$ & $310 \pm 51 \mathrm{bA}$ \\
& $42.2 \pm 3.7 \mathrm{bB}$ & $59.7 \pm 8.3 \mathrm{aA}$ & $45.9 \pm 3.9 \mathrm{aB}$ \\
Smooth bromegrass & $66.2 \pm 7.7 \mathrm{aA}$ & $54.1 \pm 8.6 \mathrm{aAB}$ & $49.8 \pm 15.1 \mathrm{aB}$ \\
Meadow bromegrass & $15.4 \pm 1.6 \mathrm{cA}$ & $19.1 \pm 3.6 \mathrm{bA}$ & $13.0 \pm 1.7 \mathrm{bA}$ \\
Triticale & & &
\end{tabular}

Values presented are means \pm standard errors for 8 replicates.

For each pool means within each column followed by different lower case letters indicate significant difference among species within grazing intensity (Least Squares Means, $P \leq 0.05$ ).

For each pool means within each row followed by upper case letters indicate significant difference among grazing intensity within species (Least Squares Means, $\mathrm{P} \leq 0.05$ ) ferences in $\mathrm{C}: \mathrm{N}$ ratio reflected variations in the root- $\mathrm{N}$ concentration. Overall the root $\mathrm{C}: \mathrm{N}$ ratio ranged between $22: 1$ and 36:1.

\section{Discussion}

\section{Litter mass, Litter $\mathbf{C}$ and N Pools}

The benefits of litter through improved soil structure and infiltration as well as decreased raindrop impact, runoff and evaporation have been reported widely (Willms et al. 1986, Naeth et al. 1990). In our study, accumulations of litter were strongly influenced by grazing intensity as well as plant species and year. The reduced amount of litter on heavily grazed treatments compared to lightly grazed ones may be attributed to greater removal of green herbage through grazing. It is also possible that heavy grazing may have accelerated litter decay through trampling compared with medium and light grazing. This result has been reported for other grasslands (Rhoades et al. 1964) including grazed lands in Alberta (Naeth et al. 1990, Dormaar and Willms 1992).

Treatment differences in the $\mathrm{C}$ and $\mathrm{N}$ pool of litter were most clearly expressed in fall. Responses in litter $\mathrm{C}$ to grazing intensity were clear with light grazing always providing more $\mathrm{C}$ than heavy. The seasonal differences in the carbon content of litter under each grazing intensity may be partly due to freezing effects (loss of cell contents) over winter. Furthermore, a concurrent study conducted on the same plots indicated that annual runoff was dominated by snowmelt-induced runoff, averaging 98,84 and $86 \%$ for the light, medium and heavy grazing, respectively (Gill et al. 1998). This implies that the physical loss of titter could have occurred during snowmelt in spring resulting in reduced litter and litter $\mathrm{C}$ pools compared with pools in fall of the previous year.

Quality of litter is reflected in the C:N ratio and lignin contents. Ultimately soil $\mathrm{C}$ and $\mathrm{C}: \mathrm{N}$ ratio will reflect litter and root characteristics that influence decomposition rates (Wedin and Tilman 1990). Because the rate of microbial decomposition is related to the $\mathrm{C}: \mathrm{N}$ ratio, it is expected that the proportion of $\mathrm{C}$ and $\mathrm{N}$ reaching the soil would be proportionately less than that indicated by $\mathrm{C}$ and $\mathrm{N}$ pools from litter. The lignin content controls the split of litter into structural and metabolic material. Most of the structural material $(70 \%)$ with high lignin is stabilized in the soil while very little is found in microbial biomass (Parton et al. 1987). 


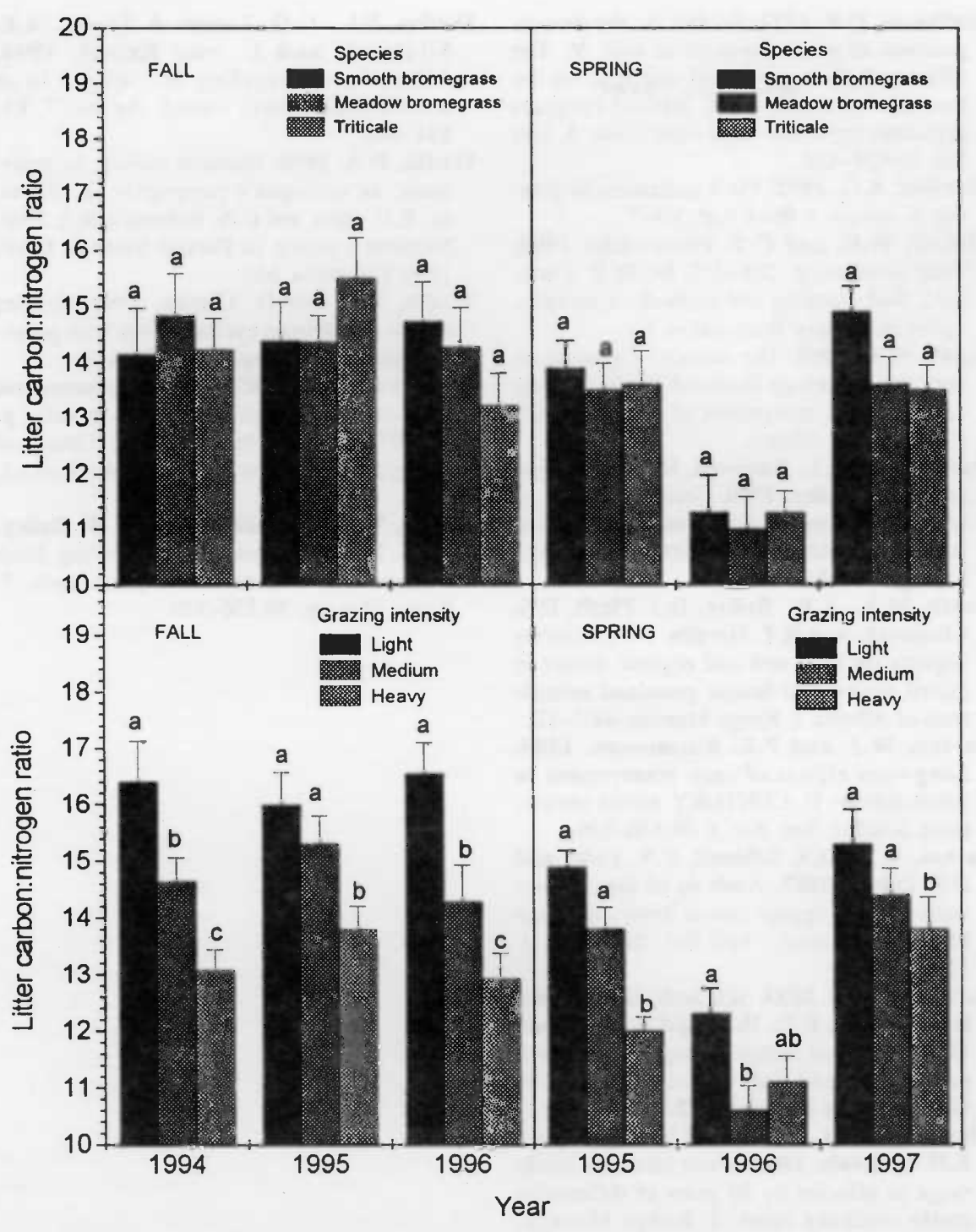

Fig. 4. Litter carbon:nitrogen ratio in fall and spring under different species, years and grazing intensities.

\section{Root Mass, Root C and N Pools}

Root mass is expected to decrease with increased grazing intensity (Briske 1991). Meadow bromegrass appeared to follow this trend for root mass with increased grazing intensity. However, smooth bromegrass under light grazing produced a lower root mass than that under moderate grazing. The difference in responses between the bromegrass species for grazing intensity is difficult to explain. Matches (1992) cited studies of other species where grazing intensity did not affect root mass (as for triticale) and Harker and O'Sullivan (1993) observed that quackgrass was stimulated to produce root material relative to untreated controls when thinned by herbicide application. Their conclusion was that rhizomatous species (like quackgrass and smooth bromegrass) might suffer from intraspecific competition for root development, when allowed to grow uncontrolled.

In this study the perennials consistently had 3.7 times the $\mathrm{C}$ and 3.3 times the $\mathrm{N}$ pools in the root material compared with triticale, possibly because perennial roots include both live and dead roots whereas triticale had mostly live roots. Turnover of root material is an important consideration in determining the annual contribution of roots to the soil $\mathrm{C}$ and $\mathrm{N}$ pool. Roots of triticale were produced annually, and annual cultivation would increase the rate of decomposition of dead roots in the surface layer. The turnover of perennial grass roots is more difficult to assess because management level can influence lifespan of roots. Grazing, cutting, and fertilizer application, tends to shorten the average turnover period (Whitehead 1995). Lifespan of roots may vary from 4 to 6 weeks to up to several years in shortgrass prairie (Whitehead 1995). Decomposition rates are greater in root material with low C:N ratios (Whitehead 1995). In a similar environment Walley et al. (1996) reported an average root turnover rate of 1 year for alfalfa and meadow bromegrass.

\section{Litter and Roots Contribution to the Stable Soil C Pool}

According to Van Veen and Paul (1981), 50\% of the litter produced annually on native grassland enters the soil. In cereal grasses $80 \%$ of the litter that enters the soil is easily decomposed while the remaining $20 \%$ is more resistant to decomposition (Jenkinson 1977; Parton and Rasmussen 1994). An estimated 63\% of the root $\mathrm{C}$ is easily degradable with the remaining $37 \%$ forming part of the resistant soil organic matter (Van Veen and Paul 1981). Using these percentages the estimated $\mathrm{C}$ contributions from litter and roots resulted in total $\mathrm{C}$ contributions to resistant organic $\mathrm{C}$ of $1,210,1,550$, and $1,810 \mathrm{~kg} \mathrm{C} \mathrm{ha}^{-1}$ for heavy, medium, and light grazing, respectively. Over the same period (i.e. 3 years), the total $\mathrm{C}$ contribution to resistant soil organic $\mathrm{C}$ was 2,608 $\mathrm{kg} \mathrm{C} \mathrm{ha}^{-1}$ for perennials compared to only $962 \mathrm{~kg} \mathrm{C} \mathrm{ha}^{-1}$ for triticale. However, these estimates are simplified because they did not take into account factors that make $\mathrm{C}$ contribution estimation more complicated, such as yearly cultivation of annual species and lignin concentration.

Within the top $30 \mathrm{~cm}$, total soil organic $C$ did not change significantly over the period of study (1994 to 1996) and was not affected by grazing treatments (Baron et al. 1999). Average soil total C concentrations over the 0 to $15-\mathrm{cm}$ depth interval were $5.3 \%$ in 1994 and $5.4 \%$ in 1997 , which is equivalent to 74 and $75 \mathrm{Mg} \mathrm{ha}^{-1}$ $\mathrm{C}$, respectively. This observation is consistent with findings on Black Chernozems with high organic matter content (Campbell et al. 1991).

In conclusion, increased grazing intensity resulted in smaller litter $\mathrm{C}$ and $\mathrm{N}$ pools. A similar trend was observed for root $\mathrm{C}$ and $\mathrm{N}$ pools. Both litter and root mass, and litter C pool for perennials were greater than that for triticale. Thus growing perennials would provide a greater litter base, greater litter $\mathrm{C}$ and root $\mathrm{C}$ pools than annuals. Amidst concern about global warming, growing perennial species may potentially enhance $\mathrm{C}$ sequestration and reduce net emission of carbon dioxide from agricultural ecosystems. 


\section{References}

Baron, V.S., E. Mapfumo, M.A. Naeth, and D.S. Chanasyk. 1999. Sustainable grazing systems for perennial and annual forages on sloped lands. Canada-Alberta Environ. Sustainable Agr. Agreement Final Rep. 161 pp.

Bransby, D.I., A.G. Matches, and G.F. Krause. 1977. Disk meter for rapid estimation of herbage yield in grazing trials. Agron. J. 69:393-396.

Briske, D.D. 1991. Developmental morphology and physiology of grasses, p. 85-108. In: R.K. Heitschmidt and J.W. Stuth (eds.), Grazing management: an ecological perspective. Timber Press, Portland, Ore.

Burke, I.C., W.K. Laurenroth, and D.P. Coffin. 1995. Soil organic matter recovery in semi arid grasslands: implications for the Conservation Reserve Program. Ecol. Appl. 5:793-801.

Campbell, C.A., R.P. Zentner, H.H. Janzen, and K.E. Bowren. 1990. Crop rotation studies on the Canadian prairies. Research Branch, Agriculture Canada. Pub. No. 1841/E.

Campbell, C.A., K.E. Bowren, M. Schnitzer, R.P. Zentner, and L. Townley-Smith 1991. Effect of crop rotations and fertilization on soil organic matter and some biochemical properties of a thick Black Chernozem. Can. J. Soil Sci. 71:377-387.

Chanasyk, D.S. and C.P. Woytowich. 1987. Sediment yield as a result of snowmelt runoff in the Peace River Region. Can. Agr. Eng. 29:1-6.

Coleman, S.W. 1992. Plant-animal interface. J. Prod. Agr. 5:7-13.

Dormaar, J.F. and W.D. Willms. 1992. Water-extractable organic matter from plant litter and soil of rough fescue grassland. J. Range Manage. 45:152-158.

Entz, M.H., W.J. Bullied, and F. KatepaMupondwa. 1995. Rotational benefits of forage crops in Canadian Prairie cropping systems. J. Prod. Agr. 8:521-529.

Gill, S.I., M.A. Naeth, D.S. Chanasyk, and V.S Baron. 1998. Runoff and sediment yield from snowmelt and rainfall as influenced by forage type and grazing intensity. Can. J. Soil Sci. 78: 699-706.

Gomez, K.A. and A.A. Gomez. 1984. Statistical procedures for agricultural research, 2nd ed. John Wiley and Sons, New York.

Harker, K.N. and P.A. O'Sullivan. 1993. Herbicide comparisons on quackgrass (Elytrigia repens) within different crop competition tillage conditions. Weed Sci. 41:94-99.
Jenkinson, D.S. 1977. Studies on the decomposition of plant material in soil. V. The effects of plant cover and soil type on the loss of carbon from ${ }^{14} \mathrm{C}$ labeled ryegrass decomposing under field conditions. J. Soil Sci. 28:424-434

Matches, A.G. 1992. Plant responses to grazing: A review. J. Prod. Agr. 5:1-7.

McGill, W.B. and C.T. Figueiredo. 1993. Total nitrogen, p. 201-212. In: M.R. Carter (ed.), Soil sampling and methods of analysis. Lewis Publishers, Boca Raton, Fla.

Naeth, M.A. 1988. The impact of grazing on litter and hydrology in mixed prairie and fescue grassland ecosystems of Alberta. Ph.D. Diss. Univ. of Alberta.

Naeth, M.A., R.L. Rothwell, D.S. Chanasyk, and A.W. Bailey. 1990. Grazing impacts on infiltration in mixed prairie and fescue grassland ecosystems of Alberta. J. Range Manage. 70:593-605.

Naeth, M.A., A.W. Bailey, D.J. Pluth, D.S. Chanasyk, and R.T. Hardin. 1991. Grazing impacts on litter and soil organic matter in mixed prairie and fescue grassland ecosystems of Alberta. J. Range Manage. 44:7-12.

Parton, W.J. and P.E. Rasmussen. 1994. Long-term effects of crop management in wheat-fallow: II. CENTURY model simulations. Soil Sci. Soc. Am. J. 58:530-536.

Parton, W.J., D.S. Schimel, C.V. Cole, and D.S. Ojima. 1987. Analysis of factors controlling soil organic matter levels in Great Plains Grasslands. Soil Sci. Soc. Am. J. 51:1173-1179.

Parton, W.J., J. M.O. Scurlock, D.S. Ojima, D.S. Schimel, D.O. Hall, and S. Copegam. 1995. Impact of climate change on grassland production and soil carbon worldwide. Global Change Biol. 1:13-22.

Rhoades, E.D., L.F. Locke, H.M. Taylor, and E.H. McIlvain. 1964. Water intake on sandy range as affected by 20 years of differential cattle stocking rates. J. Range Manage. 17:185-190.

SAS Institute, 1989. SAS/STAT user's guide Version $6,4^{\text {th }}$ Ed. SAS Institute, Cary, N.C.

Smucker, A.J.M., S.L. McBurney, and S.K. Srivastava. 1982. Quantitative separation of roots from compacted soil profiles by hydropneumatic elutriation system. Agron. J. 74:500-503

Steel, R.G.D. and J.H. Torrie. 1980. Principles and procedures of statistics: a biometrical approach. 2nd edition. McGrawHill, N. Y.

Van Veen, J.A. and E.A. Paul. 1981. Organic carbon dynamics in grassland soils. I. Background information and computer simulation. Can. J. Soil Sci. 61:185-201.
Walley, F.L., G.O. Tomm, A. Matus, A.E. Slinkard, and C. van Kessel. 1996. Allocation and cycling of nitrogen in an alfalfa-bromegrass sward. Agron. J. 88: 834-843.

Wedin, D.A. 1996. Nutrient cycling in grasslands: an ecologist's perspective, p. 29-44. In: R.E. Joost and C.A. Roberts (eds.), Proc. Nutrient Cycling in Forage Systems Conf. 1996, Columbia, Mo.

Wedin, D.A. and D. Tilman. 1990. Species effects on nitrogen cycling: a test with perennial grasses. Oecologia 84:433-441.

Whitehead, D.C. 1995. Amounts, sources and fractionation of organic nitrogen in soils, $p$. 82-107. In: D.C. Whitehead (ed.), Grassland nitrogen. CAB International, Wellinford, U.K.

Willms, W.D., S. Smoliak, and A.W. Bailey. 1986. Herbage production following litter removal on Alberta native grasslands. J. Range Manage. 39:536-540. 